\title{
Sustainable development of system of social-labor relations in conditions of transformation of labour and entrepreneurship
}

\author{
Nazarova Ulyana Anatolyevna \\ Institute of Economics, Finance and Business \\ Bashkir State University \\ Ufa, Russian Federation \\ nazarovaua@mail.ru \\ Galimova Aigul Sharifovna \\ Institute of Economics, Finance and Business \\ Bashkir State University \\ Ufa, Russian Federation \\ aigul_galimova@mail.ru
}

\author{
Alekseev Oleg Aleksandrovich \\ Institute of Economics, Finance and Business \\ Bashkir State University \\ Ufa, Russian Federation \\ aleksoa@yandex.ru \\ Galina Albina Eduartovna \\ Institute of Economics, Finance and Business \\ Bashkir State University \\ Ufa, Russian Federation \\ galinaae@mail.ru
}

\begin{abstract}
The relevance of the problem under study is due to, on the one hand, narrowness of the methodological basis of modern labour economics for formation of a single subject field of interdisciplinary studies of social and economic transformations of the labor and entrepreneurship in the modern world. On the other hand, there is insufficiency of available methodological and methodical tools for the study of new social phenomena, born by contemporary transformations of labor and entrepreneurship. The article is aimed at substantiation of the holistic (integrative) approach to studying labor and entrepreneurship problems and creation of a unified theory of labor and entrepreneurship, as relevant tools of changing labor study in the context of a new social reality. Socioeconomic analysis is the leading method in solving the problem that allows revealing the two-way communication of economic and social processes and introducing studies of labor and entrepreneurship into the wider social context. The article shows a number of steps, making it possible to overcome the peripheral status of the labor economics and introduce it into the methodological core of modern social researches through a significant expansion of the object field of researches, updating methodological tools and increasing interdisciplinary interaction with non-economic sciences. It is shown how the complication of a conceptual labor model based on the principle of duality and bilateral socioeconomic consideration of the research subject can reveal the heuristic potential of labor socioeconomics, while retaining analytical advantages of the cost analysis, developed by the labor economics. Article materials can be useful for researchers who are interested in the issues of methodology of labor economics, labor sociology, and for a wider range of scientists and experts engaged in the development of technologies and system solutions of labor and entrepreneurship problems.
\end{abstract}

Keywords-labor methodology, socioeconomics, labor economics, labor sociology, subject area of labor studies, socioeconomic theory of labor and entrepreneurship.

\section{THE SYSTEM OF SOCIAL AND LABOR RELATIONS AND ITS SYSTEM FEATURES}

Today in science and practice, there are different interpretations of social and labor relations. The most frequent variant is when social and labor relations are understood as mass relations arising among participants of production during their interaction concerning remuneration for work, its conditions, employment, forms and methods of conflict resolution [20]. A more concise definition is social and labor relations are relations in the sphere (concerning) of labor activity [14]. In the authors' opinion, complications at the level of conceptual framework are not required, however, the systematic approach to understanding is necessary. That is why it is advisable to determine social and labor relations as systems of socio-economic relations concerning elements of labor activity. At the same time, it is important to take into account that there are a lot of elements of labor activity, but not all of them will be significant, influencing labor behavior. First of all, these are salary, employment conditions, working hours, promotion. Elements, meanwhile, may have different character, for instance, a cost one - if it is about salary, or psychological - if it is about non-material motivation.

The system of social and labor relations has all the system features. Let us consider them briefly.

Since in universal understanding a system is regarded as a plenty of interactive elements that are in relations and interconnections and that form a whole unit [5], then the first system feature is its integrity - the unity of all elements. Indeed, the system of social and labor relations is characterized by integrity of subjects of social and labor relations as well as of elements of these relations. For example, the presence of one of the subjects, either an employer or employee, implies the presence of the other one. The historical practice of elimination of one of them, for 
example, the Soviet system that deformed the class of employers, eventually, appeared to be unviable. Secondly, all subsystems that are formed at different levels of production hierarchy: high, middle, low, are closely connected with each other, without which the production process is impossible. It is this system property that indicates that any changes in work, whether it is salary or a social partnership procedure, should affect all subsystems, namely, all levels of managerial hierarchy.

The system of social and labor relations also has a synergistic effect. A synergistic multiplicative effect in complicated systems is an effect of a considerable rise of total activity of separate elements in contrast to simple adaptive summation of constituents [6]. Moreover, the system of social and labor relations is so integral that elements almost cannot exist separately. Thus, an employer or an employee separately will not be able to carry out the production process. All the scientists, starting with the classicists of economic thought, admitted inefficiency of labor without capital and vice versa.

An important system property is purposefulness. Purposefulness is a property of complicated, active systems to develop purposefully, changing their states, main characteristics and structure in such way that they approach closer to the intended purpose. As a rule, as a result of purposeful development, main system parameters and characteristic improve [6]. This property overlaps slightly with the feature of system completeness. However, not only the system capacity to change, but the capacity to change purposefully, i.e. to evolve over time, is important here. If one determines economic progress as a purpose, then the system of social and labor relations has this property. For example, there is a replacement of a main employer function carrier by implementation of a tool of employee participation in management and capital. Toughness of intersubjective relations decreases, the structure of working class changes, etc. As a result, there is acceleration of economic growth rate that, according to predictions, will continue further. So, it is predicted that the world economy will grow by $80 \%$ by 2020 in comparison with 2000 , and the average per capita income will grow by $50 \%$ [16].

At the same time, it is necessary to take into account such system duality as two development goals at once: economic and social. As a rule, goals of social development are achieved by this system by means of movement to economic goals. Thus, despite the average income growth, differentiation in society, as in Russia, leaves appreciable. On the contrary, poor expression of achieving economic goals in the Soviet period of Russia was at the same time characterized by social equality. Thus, the world experience indicates vividly that the achievement of economic goals is closely connected and supported by social orientation of the system. Thus, having passed the acute phase of social conflicts, the system of social and labor relations on the West after the 1930s of the XX century began to move both to economic and social goals such as development of industrial democracy, humanization of labor, social responsibility of business. All this predetermines the ability of this system to self-organization. As G. Bremmermann formulated, a self-organizing system is a system that strives to improve its characteristics and structure while achieving the specified goal and that implements such improvement without outside help [5]. However, still, there is outside help for this system. Here one observes the realization of this duality: in achieving economic goals the system of social and labor relations, being self-organizing, sets social goals and improves its parameters under external influence of state or society. For example, development of such system element as a mechanism of social partnership was not only the result of inside system evolution but also was actively stimulated by government as external force.

When one talks about the system of relations, immediately the question about subjects of these relations arises. And here one comes across the second duality of this system, namely, the presence of two levels: individual and collective [21], which leads to the need for using dialectical methodology of deductive and inductive study. Thus, when studying the system of social and labor relations, it is necessary to take into consideration both macro-, and microlevel in their interrelation and interdependence, where on the macrolevel subject segregate employers and employees and on the microlevel - employers and employees within one organization.

The third duality of this system based on the cost analysis. In the system of social and labor relations can be divided two discussion fields which are formed by depending on the creating and distributing value. The first field concerns the analysis of the distribution of value between labor and capital. Proponents of the labor theory of value believe that labor is the only source of value, and here starts the theory of exploitation. Proponents of the theory of factors of production think that labor is only one of many factors, so the task is only in the reasonable pricing.

The second field in the analysis of the system of social and labor relations appears if approach the theory of value from the position of neo-Marxist interpretation [13], when the concept of labor expanding as a source of value on the organization of production. On this basis, the business factor, as well as any managerial activity in the organization of production can also be attributed to labor, as the enterprise and production organization associated with the intellectual and organizational activity of man in the production process. Thus, if extend the concept of living labor (wage workers) as a source of value to the work of the employer (the owner organizing the process, Manager, etc.), then in a certain way Marxist theory is consistent with the factor of direction economic-value analysis and the surplus value is included in the newly created value (living labor) as a form of remuneration for labor. Hence, the theory of operation will be presented in a slightly different key. Namely, not as an assignment by the employer who does not create a value, but as a non-equilibrium division of value within the labor factor means between types of labor. Using the neo-Marxist approach allows us to consider the antagonism between social and labor relations not as their attributes, but as the specific historical condition, which can be overcome by harmonization of relations between the employer and the employee. Thus, studying the system of social and labor relations, we have to consider the duality of the problem field. The first stratum of problem analysis is distribution of value between labor and 
capital. The second stratum is the distribution of the cost between the employees and the executor of the employer (management and business factor) as special kinds of work. At this article, let the figure be the first aspect, especially the question of distribution a newly created value among labor and capital as the most important condition of sustainable development of the system of social and labor relations.

\section{THE DISTRIBUTION OF VALUE BETWEEN LABOR AND CAPITAL AS THE REQUIREMENT FOR STABLE DEVELOPMENT OF THE \\ SYSTEM OF SOCIAL AND LABOUR RELATIONS}

In scientific research in the framework of a systematic approach, it is quite often to meet such important property or the criteria system as sustainability. So, V.A. Kardash notes, "economic equilibrium is defined as that condition of the economic system, in which system process is formed by the set rules of negotiation - as the result of the interests of all economic entities in the form of a generalized index of achieving static stability of the economic system as a whole" [8]. In relation to the system social and labor relations, we can talk about sustainability as the basis for further development of the system, specifically functioning when reach the objectives of economic growth and social well-being. In that way, sustainable socio-economic development of the system of social and labor relations is characterized by a state, when all production resources are used with maximum socioeconomic efficiency. The efficiency of the production is the ratio of the useful results and the costs of factors of production [23]. Moreover, as noted above, we mean not only economic but also social results. In this sense, social development of society is the process of purposeful social change, in which successive states of society and all social groups is preferable to the previous one [19].

It seems that the most telling criterion for such stability is the ratio of the distribution of newly created value between labor and capital.

To estimate the distribution of newly created value among labor and capital, indicators such as the ratio of wages in gross domestic product (GDP) are used for the region in gross regional product (GRP) or gross value added, in case we study a subsystem of lower order: industry or organization.

According to the A. Bowley's law:"relative shares of labor and property in the functional distribution of income at least in the private sector are permanent". John.M.Keynes also shared this point of view, saying that "the stability of the share of labor in national income is one of the most striking and the most reliable facts in the whole economic statistics". However, the researchers, based on statistical data, says that already from 1929, there were facts that did not support these patterns. Thus, countries with a market economy began to show growth in the share of labor. For example, the proportion of remuneration in Belgium has increased from 36.9\% in 1948 to $59.8 \%$ in 1975 [7]. It does not mean that in developed countries the upward trend in the share of labor in distribution cost was stable throughout the whole historic period. According to the ILO report, the average value of the labour share in 16 developed countries dropped from about $75 \%$ of the national income in the mid-1970s to about $65 \%$ by 2013
[4]. Thus, we see a "wave" in the dynamics of the share of the value created in the developed countries, attributable to the labor factor, the drop-down portion of which has still not led to the return of low values, and stopped at $50-65 \%$ and nowadays is fairly stable, although it is difficult to make complete projections. It is difficult to accurately identify the cause of such fluctuations. It is possible to assume that this is due to activation and attenuation of the Trade Union movement. If this is true, then in the case that the world economy will go by the way of reducing the share of labour in distribution the cost, countries could face a deterioration of the social component and an increase in social conflicts in society. In our opinion, the increase salary in developed countries has become one of the major bases for economic growth, and therefore for the sustainable development of the system of social and labor relations, it is necessary to return to sustained growth in the share of labor from creating value.

As for Russia, since 2000, in the structure of gross domestic product, the official salary of employees shows a small but steady upward trend and today corresponds to that value of many European countries and it is higher than the average value in developing countries. Thus, when assessing the ratio of the share of wages in GDP of the Russian Federation and Western countries, we should consider that the statistics of the national accounts in Europe and the United States can only find official "clean" wages. If we assume that among the countries of Western Europe and the United States the place where hidden wage does not exist, we can conclude that the share of wages in GDP of Russia is at the level of socio-oriented developed countries [7].

However, the system of socio-labor relations in our country is not so well. If we look at the industry cut, in a number of key sectors, the difference in proportion of cost attributable to labor wages is different from the West in two or more times. For example, according to the data for 2011 for the industry of "production of cox and oil products" on labour wages of employees in Russia accounted $7.1 \%$, and in Germany $-39.1 \%$ of [7], it means that in Russia this indicator is lower by more than 6 times.

In a number of industries, the dynamics of the time also shows a decline in the share of the labour factor. Thus, in the processing production the share of wages for 10 years, since 2002 , has decreased from $43.4 \%$ to $38.7 \%$. In other words, the profits of the owners here grew up faster than wages [7]. In addition, the crises 2009 and 2014 again moved the share of wages downward, and this trend has continued in 2017. If Russia does not come to the path of growth of the wage share soon that, in our opinion, can significantly reduce the stability of the Russian system of social and labour relations. Thus, for the stable development of the system of social and labor relations is necessary, firstly, to carry out carefully to the regulating level of industrial analysis of labour share in the created value and, secondly, enter the trend of permanent growth of the share of labor factor as a guarantor of stable socio-economic development. This need to enhance the role of labour in public consciousness and in the system of value distribution. 


\section{THE PARADIGM OF LABOUR AND ENTREPRENEURSHIP} AND ITS IMPACT ON SOCIO-ECONOMIC DEVELOPMENT IN THE

\section{CONDITIONS OF TRANSFORMATION OF LABOUR VALUES}

As known, the labor paradigm was one of the dominant paradigms of social scientific knowledge development at the early stages of the economics and sociology development. Labor theories of value dominated in the classical political economics. The doctrine of Marx, representing the social development theory [12], at the same time was the most influential labor theory, and K. Marx himself was considered by many reputable scientists in the West, as the creator of still unexcelled labor philosophy [26]. The works of such classics of sociological thought as Karl Marx, Max Weber, W. Sombart, Emile Durkheim, wherein the labor played a pivotal role for construction of a social reality, served as the foundation, whereon a building of industrial society research methodology was erected in the course of more than a century. In the works of succeeding generations of sociologists this type of society providing the mass employment of simple, reproductive labor, received the characteristic as the "labor society," emphasizing the labor also as a fundamental element of culture.

Cultural specialists and social scientists were the first who became aware of the coming social transformations associated with reduction of the labor volume in the production area of the society and change in the social role of labor. Next to cultural specialists and social scientists, who since the 60 s of the past century predicted "leave of the labor from the society," "labor death," "labor degradation" (J. Baudrillard, R. Dahrendorf, A. Gorts, D. Bell, A. Turen, K. Offe, A. Toffler, U. Bek, P. Kozlovski et al.), economists began to bespeak the "disappearance of labor". However, if the shocking concept of "labor death" should have stimulated the search for answers to historical challenges of the technological and social progress and return the varying labor phenomenon into the center of scientific discourse from the standpoint of cultural specialists, some economists understood the "farewell to labor" too literally.

No such ides befell the Russian society too. In the late 80 s - early 90s the soviet social science, including labor sociology, appeared to face challenges, to which failed to give an adequate answer. Since the beginning of the 90s, when the domestic social science attempted to rethink Marxist heritage, culminated later by the break with the Soviet school of Marxism, social labor problems were pushed into the background, giving a way to the package of problems of transitional economy and labor market formation. The "labor" concept disappeared from economical dictionaries and encyclopedias.1 Econometric approach, defined by appetences of economics adherents, to construct an economic labor theory based on the model of Labor economics course, taught in Western universities. [11], [17] prevailed in the substantially narrowed field of labor problems studies. Labor market began to act as a main subject of the labor economics research.

${ }^{1}$ There is no "Labour" category in the New Economic encyclopedia addressed to all "who would like to better understand the economic issues" [18]. There is "the structure of society financial and economic relations" in the index, the "shadow economy" is present as well, but there is no labor.
Adherents of this trend see the labor economics as the most "pure" and positive economic-labor science among all of labor sciences. "The behavior of enterprises and individuals is considered in it as the economic behavior, determined primarily by the ratio of profits and losses, rather than existing norms and traditions. All other labor sciences contain a significant non-economical component" [3]. Claims to a general-methodological status of labor economics aimed at serving as a theoretical basis for all other labor sciences are expressed at the same time. Although some authors recognize the beneficial nature of labor economics interaction with various non-economic disciplines, generally, economists are not disposed to increase such collaboration beware of the own methodological basis "dilution."

However, in all fairness it has to be noted that the withdrawal of the scientific discourse from the labor social problematics turned out to be short. It is true noticed that the new labor notion is created in times of crises, during "peak hours" of history [9], when appears the need for understanding and mastering a new social reality.

A purely "market" problem in last few years leaves the subject field of Russian researches of labor problems. More and more researchers are selecting topics socio-economic thematic, and in both thematic areas - economic and social sciences [10].

Recognition of labor economics subject duality can serve as the first step - recognition of labor as a complex socialeconomic process, wherein not only technical-technological, technical-organizational and economical sides related to creation and consumption od the value is detected, but also a close interrelationship of economical and social, wherein the labor acts as the genetic basis for creation and modification of both labor organization social forms and life organization social forms.

Basic grounds of the social-economic approach were laid by K. Marx and if modern economists can point to the weak spots of Marx's theory in a number of economic rationales and conclusions, then his social-economical methodology has unquestionable value, showing the limitation of existing socioeconomical models, giving preference to the study of unilateral influence of social processes on the economy ${ }^{2}$. But "...social relation, production relation, - Marx emphasized - is, in fact, even more critical result of the process [labor] than its material results" [12]. Consideration of labor as a social process which received a methodological substantiation in the works of Karl Marx, gives the necessary trend for socioeconomic analysis of labor problems and the basis for structuring the expanding subject area of labor socialeconomic studies [1].

As the next step, complicating the conceptual model of labor, can serve introduction of the power parameter. In the real economy, there is a constant struggle between economic

${ }^{2}$ At the same time, the back impact of the economy on social processes is overlooked. Sufficiently profound and meaningful analysis of limitations of socio-economics in the version, proposed by the International Society for the Development of Socio-economics (SASE) and its founder A. Etzioni is given by M.A. Shabanova [22, 24]. 
entities for appropriation, retention and redistribution of control means over factors of production (labor, capital, etc.). In this struggle, certain groups of entities try to subordinate others and achieve dominancy, not limited to purely economic methods. The more set of managerial functions and control means over resources and factors the entity captures, the greater its impact on the economical mechanism, as well as the greater the economic strength and power it acquires. Accordingly, the more effective for it is the process of the value estrangement and appropriation as well as readjustment of the economic system for own benefit, including for extraction of the rent too. As it is rightly pointed out by Charles Anderton: "Throughout its history, economics has generally ignored the effect of the appropriation possibilities on production and exchange. Often, however, three economic activities are enmeshed" [25]. Hence Anderton believes that it is important to review all basic economical concepts and analytical variables (production, consumption, market, value, relative price) taking into account possibilities of misappropriation and, correspondingly, necessary expenses for protection, including the cost of attack instruments and conducting conflict actions.

The ambivalence of the socio-economic position of entrepreneurship can be of particular interest in this regard for the expanding area of socio-economic labor studies. Entrepreneurship should be understood, as a special type of the historically formed economic-labor activity [1] and should be included in the subject field of labor studies. It arose in response to the social need in detecting unsatisfied demand and meeting increasing demands of people through the organization of production. The entrepreneurship activity, considered in this aspect, appears as an element of labor and social production system division, and does not stand against the labor as the productive activity. But this, by no means, does not exclude the contradiction between labor and entrepreneurship in other relations. The entrepreneurship internal contradiction has, as the origin, the labor cost function aimed at creating the value for the purpose of its assignment in monetary form, but not in the form of use value. This historically new labor function provided the basis of "selfgenerating growth abstract form" [15] of the capitalist market production, and formed an entrepreneur, as its main driving force. Modern entrepreneurial practice gives a lot of examples, when in the pursuit of profit, bases of economic life of entire countries and peoples are destroyed, when the use of unfair practices becomes the alternative of increasing competitiveness through increasing qualitative characteristics of the production capital (new equipment, technologies, professional knowledge and competence of the staff, improvement of business architecture, etc.). It would seem that we have a similar set of entrepreneurship features in the latter case: risk, inventiveness, striving for the profit extraction. Even peculiar "innovation" while conducting such "business" takes place. If proceed from a "pure" (emasculated) functional approach, summing up a set of functional features only, suchlike "celebrities" quite can fall into the entrepreneur category, although in fact they do not develop, but rather destroy the economic mechanism, do not create a social value, but waste it. The activity of such-like predator entrepreneurs (predators) can lead to both direct losses of the created value and indirect losses as a result of the market price coordination violation (i.e., to deterioration of market assessment mechanism of resources, as is well-known, the actual market-price of a resource is determined by its best alternative use). In other words, their activity bears the entropic nature [2]. The nature of the entrepreneurial activity - creative or destroying essentially depends on the motivation which determines the trend in the choice of one or another form of conducting business, one or another form of increasing competitive advantages, etc.

So, the focus of attention for the sustainable development of the system of social and labor relations should be the paradigm of the growing importance of labour and entrepreneurship. Regulatory impact on the social and labor sphere must not be unilateral; it must be bilateral and proceed from a close "relationship of the economy and society" at all levels of regulation. For example, the nature of the functioning of the integrated capital (financial, production, human, social) should be evaluated in the parameters of its realization in the level and quality of life, development of social infrastructure, etc. And on the other hand, the nature of development of knowledge, high technologies, engineering, new forms of organization of labor and production must obtain a valuation from the point of efficiency and increment of capital circulation.

\section{References}

[1] O.A. Alekseev, F.U. Mukhametlatypov, Labor and entrepreneurship socioeconomic model. Ufa: RIO Bashkir State University, 2005.

[2] O.A. Alekseev, "Entrepreneurship value contradiction: system and valuation-motivational bases of resolution and creativeness", European Social Science Journal, vol.3, pp. 7-12, 2015.

[3] N.A. Gorelov, Labor Economics: short course. St. Petersburg: Piter, 2007.

[4] Report «Salary in the world in 2012-2013. Salary and reasonable growth. International job management, 2013, p. 44.

[5] A.B. Doktorovich, Social-oriented development of a society: theories and methods of system research. Moscow: Publishing house «IKAR», 2003, pp. 59-60.

[6] Y.V. Gusarov, Management: dynamics of disbalance. Moscow: CJSC Publishing house «Ekonomika», 2003, p. 18.

[7] A.L. Zhukov, Salary regulation: modern tendencies and ways of reforming: monograph. Moscow: PH ATiSO, 2014, pp. 90-91.

[8] V.A. Kardash, Conflicts and compromises in market economy. Moscow: Science, 2006, p. 43.

[9] E.A. Klimov, Introduction to labor psychology. Moscow: Culture and Sports, YuNITI, 1998.

[10] R.P. Kolosova, V.N. Bobkov, "Modern approaches to labor economics", Living standards of the population of Russian regions, vol. 6 (184), pp. 25-37, 2013.

[11] M.G. Kolosnitsyna, Labor Economics: teaching guide for bachelor degree course students of universities and colleges. Moscow: Magistr, 1998.

[12] K. Marx, F. Engels, Works, 2nd ed., vol. 46 (P.I). Moscow: Political literature publishing house, 1968.

[13] V.V. Radaev, Economic sociology: teaching guide for universities. Moscow: Publishing house SU HSE, 2005, pp. 410-415.

[14] G.Y. Rakitskaya, Social-labor relations. Common theory and problems of their democratic regulation's development in modern Russia. Moscow: Institute for perspectives and problems of the country, 2003, p. 65 . 
[15] E.Y. Rezhabek, Capitalism: self-organization problem. Rostov-on-Don: Publishing House of the Rostov University, 2004.

[16] Russia and the world in 2020. Global future outlines: Report of National Intelligence council of the USA. Moscow: Publishing house «EUROPE», 2005, p. 15.

[17] S.Y. Roschin, T.S. Razumova, Labour economics: economical labor theory: Teaching guide. Moscow: INFRA-M, 2001.

[18] E.E. Rumyantseva, New economic encyclopedia. 2nd ed. Moscow: INFRA-M, 2006.

[19] Social politics. Encyclopedia. Moscow: Publishing house «Alfa-press», 2006, p. 329.

[20] Social partnership. Problems and perspectives of development. Collection of scientific articles. Moscow: Publishing house RASS, 2003, p. 21 .
[21] T.S. Sulimova, "Social partnership as the institute of social-labor relations' regulation", Social partnership: Problems and perspectives of development, pp. 21-22, 2003.

[22] M.A. Shabanova, "Socio-economics and economic sociology: points of delimitation and integration", Economic sociology: electronic magazine, vol. 6 (5), pp. 12-27, 2005.

[23] A.I. Scherbakov, Labor efficiency: problems and perspectives. Moscow: Znaniye, 2004, p. 14.

[24] A. Etzcioni, "Socioeconomics: further steps", Economic sociology: electronic magazine, vol. 3 (1), pp. 65-71, 2002.

[25] C.H. Anderton, R.A. Anderton, J.R. Carter, "Economic activity in the shadow of conflict", Economic Inquiry, vol. 37 (1), pp. 166-179, 1999.

[26] G. Mikl-Horke, Organisierte Arbeit. Einfuehrung in die Arbeitsoziologie. Muenchen: Oldenbourg, 1988. 